\title{
ADVOKASI MASYARAKAT DALAM \\ PENYELESAIAN SENGEKETA LINGKUNGAN HIDUP \\ DI JATEN, KABUPATEN KARANGANYAR
}

\author{
Absori \\ Fakultas Hukum \\ Universitas Muhammadiyah Surakarta
}

\section{ABSTRACT}

The problem of this public service is how to realize the autonomic people power to do the advocate of environment in order to overcome the environmental conflict. In the training of the advocate of environment, the victims of pollution-most of them are farmers and low educated people-are very enthusiastic to join the training. They are curious to know how to struggle for their polluted environment as the result of the misconduct of irresponsible companies. In the effort of this advocate of environment, the NGO "Gita Pertiwi" also gives significant contribution. It tends to cooperate with the society in order to do the advocating process. Yet, the previous activity is conducting dialogues with the society about the pollution problem. Besides, they attempt to facilitate the society to figure and find out the solution of the problem.

Key words: Environment, society, advocate.

Kata kunci: lingkungan hidup, masyarakat, advokasi

\section{PENDAHULUAN}

Kehadiran industri dan perilakunya seperti yang terjadi di Jaten, Karanganyar telah menimbulkan pencemaran lingkungan yang mengakibatkan kerugian terhadap masyarakat dan lingkungan. Para petani yang menjadi korban limbah mengalami gagal panen karena air dan tanah lahan pertaniannya tercemar. Kalaupun panen hasilnya menurun karena padi yang dihasilkan kualitasnya rendah. Sementara masyarakat yang tinggal di Mojosongo, Solo merasakan bau menyengat dan gatal-gatal ketika mandi di sungai dan tidak lagi dapat menggunakan air sungai untuk kebutuhan sehari-hari.

Membicarakan pencemaran lingkungan akan berkaitan dengan hubungan masyarakat manusia dan alam lingkungan secara kodrati sebenarnya 
keduanya merupakan satu kesatuan kehidupan sebagai biotic community. Manusia dan komunitasnya di samping diberi hak untuk memanfaatkan, juga mempunyai tanggung jawab untuk menyelamatkan dan melestarikan lingkungan. Dalam falsafah Jawa manusia (jagat kecil) merupakan bagian dari alam (jagat besar). Keberadaan keduanya merupakan satu kesatuan. Manusia memiliki tugas untuk memelihara dan memuliakan alam lingkungan yang kesemuanya bertujuan untuk kesejahteraan manusia sendiri.

Karena itu, manusia tidak diperbolehkan memperlakukan alam lingkungan melebihi dari kadar yang ada, apalagi bertindak melampaui batas terhadap alam. Tradisi sedekah bumi atau sedekah laut yang sering dijumpai dalam masyarakat Jawa merupakan simbul dari menyatunya manusia dengan alam lingkungannya, sekaligus sebagai bentuk penghormatan, rasa syukur, dan terima kasih manusia terhadap alam lingkungan yang telah melimpahkan anugerah begitu besar kemakmuran untuk kesejahteraan manusia

Berdasarkan abservasi lapangan dari beberapa kasus penyelesaian sengketa pencemaran lingkungan diperoleh gambaran permasalahan yang dihadapi masyarakat korban pencemaran lingkungan adalah bagaimana mewujudkan penguatan kekuatan otonomi masyarakat Jaten, Karanganyar dalam melakukan advokasi lingkungan hidup, yang ditunjukan melalui kemampuan untuk melakukan tuntutan atau pilihan penyelesaian sengketa lingkungan. Dalam hal ini dengan dibantu Perguruan Tinggi dan LSM seperti Gita Pertiwi memainkan peran penting dalam memberi pengetahuan dan tata cara dalam melakukan advokasi lingkungan. Apa yang dilakukan merupakan respon terhadap pembangunan melalui industrialisasi yang telah menimbulkan persoalan lingkungan di sekitar Jaten.

\section{METODE KEGIATAN}

Kegiatan dilakukan dengan cara pelatihan yang diikuti oleh anggota masyarakat korban pencemaran akibat adanya pembuangan limbah yang dilakukan pihak perusahaan. Pada pelatihan yang dilaksanakan patanggal 4 Juni 2005 di Wisma Soeharso, Colomadu, Karanganyar, diikuti sekitar 30 orang warga masyarakat dukuh Sawahan, Jaten, Karanganyar. Metode kegiatan dilakukan dengan ceramah, peragaan dan dilanjutkan dengan dialog atau tanya jawab. Dalam kegiatan tersebut dibantu oleh LSM Gita Pertiwi, sebuah LSM yang bergerak di bidang lingkungan. 


\section{HASIL DAN PEMBAHASAN}

Dalam pelatihan advokasi lingkungan masyarakat korban pencemaran sekalipun rata-rata sebagai petani dan berpendidikan rendah tetapi tampak semangat untuk mengikuti materi pelatihan. Mereka ingin mengetahui banyak bagaimana cara memperjuangkan lingkungannya yang sudah tercemar. Dalam hal ini masyarakat yang terkena dampak pencemaran lingkungan akibat limbah industri di Jaten, Karanganyar secara sosio-ekonomi berada dalam kehidupan yang sederhana, yang ditandai dari mata pencaharian hidup mereka yang lebih banyak mengandalkan pada sektor pertanian sebagai gantungan hidupnya. Jika dilihat dari segi pendidikan, meraka rata-rata berpendidikan rendah dan tidak mempunyai keterampilan selain bertani, menjadi nelayan atau pedagang. Kalaupun ada yang berpendidikan tinggi, mereka enggan untuk kembali ke kampung halamannya menekuni profesi sebagaimana yang ditekuni orang tuanya. Mereka lebih senang tinggal di kota mengadu nasib dengan berbekal izasah yang dimilikinya sehingga tidak memberikan banyak kontribusi yang berarti bagi persoalan yang sedang dihadapi masyarakat di desanya.

Masyarakat yang berada di daerah Karanganyar menunjukan corak yang lebih tertutup dan cenderung menunggu dalam menyelesaikan sengketa lingkungan. Di samping itu, mereka lebih adaptif dengan budaya yang berakar dan hidup dalam komunitas masyarakat sehingga lebih mudah untuk didorong pada upaya untuk menyelesaikan sengketa lingkungan dengan cara musyawarah. Kalaupun ada upaya melalui pengadilan sebagaimana yang terjadi di Karanganyar, kasusnya lebih banyak diambil alih oleh parat penegak hukum karena jalur yang ditempuh melalui jalur pidana.

Dalam masyarakat yang sederhana dalam menyelesaikan sengketa di antara mereka lebih akrab dengan cara yang lebih menonjolkan kekeluargaan dengan cara musyawarah. Hanya sebagian kecil masyarakat yang menjadi korban limbah tergolong masyarakat perkotaan, seperti yang terdapat di Solo yang mempunyai tingkat kehidupan lebih baik karena mereka berada di wilayah daerah kota dan pengembangan kota Solo. Sekalipun demikian mereka masih mempunyai tradisi yang kuat dalam menghadapi sengketa dengan mengedepankan pada nilai kekeluargaan.

Menurut Chambliss dan Seidman dalam masyarakat yang sederhana yang hanya sedikit mengenal konflik, keberadaan masyarakat dan pembuatan hukumnya lebih banyak bertumpu pada kesepakatan di antara para warganya mengenai apa yang seharusnya diterima sebagai nilai-nilai yang harus

70 WARTA, Vol.10, No. 1, Maret 2007: 68 - 75 
dipertahankan di antara warga masyarakat. Dalam masyarakat yang sederhana seperti dengan kebiasaan menyelesaikan sengketa secara kekeluargaan untuk menghindari permusuhan sesungguhnya merupakan kekuatan sosial yang disebut sebagai budaya hukum, dianggap sebagai alasan mendorong masyarakat dalam menggunakan media penyelesaian sengketa.

Sebaliknya, dalam masyarakat yang berubah yang di dalamnya sarat konflik, maka masyarakat dan pembuatan hukumnya berada dalam kondisi prubahan dan tekanan konflik dimana warganya mengalami tekanan-tekanan oleh sementara warga yang lain. Dalam hubungannya pranata yang dipakai oleh suatu masyarakat dalam menyelesaikan sengketa, maka masyarakat yang kurang terlapis atau kurang kompleks akan cenderung untuk memakai pola penyelesaian berupa perukunan. Sebaliknya dalam masyarakat dengan perlapisan sosial yang tinggi dan lebih kompleks, kecenderungannya pada penerapan peraturan-peraturan.

Hubungan antara masyarakat dengan hukum yang dipakai, Max Weber membuat tahapan perkembangan hukum, pertama, bersifat kharismatis yang bertumpu pada keistimewaan seseorang, kedua, tradisonal, mendasarkaan pada tradisi yang turun-temurun, dan ketiga, rasional berdasarkan penggarapan hukum secara sistemis dan rasional. Beberapa tahapan tersebut menjadi proses bekerjanya hukum yang berbeda karena keadaan masyarakat yang berbeda. Masyarakat Indonesia menurut Esmi Warassih berada di bawah dominasi tradisional dan kharismatis sehingga penafsiran norma hukum di samping ditentukan oleh aparat penegak hukum juga oleh bentuk dominasi yang ada di dalam masyarakat yang bersangkutan.

Lebih lanjut dikatakan bahwa hukum bukan sesuatu yang sekadar menjadi bahan pengkajian secara logis-rasional, melainkan hukum dibuat untuk dijalankan. Perwujudan tujuan, nilai-nilai, ataupun ide yang terkandung dalam hukum merupakan suatu kegiatan yang mempunyai hubungan timbal balik yang erat dengan masyarakat. Oleh karena itulah, dalam membicarakan masalah tersebut struktur masyarakat tidak boleh diabaikan. Setiap struktur masyarakat memiliki ciri-ciri yang dapat memberikan hambatan-hambatan sehingga hukum sulit untuk dijalankan, dan di sisi lain memberikan dukungan berupa penyediaan sarana-sarana bagi kehidupan hukumnya. Hukum juga memberikan kesempatan kepada masyarakat untuk menentukan pola perilakunya sendiri dalam batasbatas hukum yang telah ada. 
Dalam menghadapi persoalan hukum berupa sengketa (konflik), masyarakat sebenarnya memiliki suatu kekuatan yang bersifat otonom. Kekuatan ini eksis dan datang secara serta merta dari dalam masyarakat dan tidak diturunkan dari sumber lain, kecuali masyarakat itu sendiri dan karena itu disebut sebagai kekuatan otonom atau asli (oerkracht, original power). Kekuatan ini hadir secara alami mendahului kekuatan-kekuatan lain yang dibanding dengan kekuatan otonom tersebut lebih bersifat artifisial. Tanpa melalui macam-macam prosedur dan persyaratan, kekuatan otonom tersebut mengaksentualisasikan dirinya spontan sesuai dengan kebutuhan masyarakat sebagai suatu bentuk kehidupan bersama. Salah satu persyaratan bagi adanya kehidupan bersama adalah suasana keteraturan dalam hubungan antara para anggota masyarakat. Kalau masyarakat membutuhkan keteraturan dan ketertiban, kekuatan otonom tersebut akan menampilkan dirinya dalam bentuk kekuatan untuk mengatur (sendiri) masyarakat dan akan melahirkan sendiri berbagai kaidah dalam hubungan sesama anggota masyarakat.

Menurut Mansour Fakih tumbuhnya sejumlah organisasi gerakan advokasi lingkungan, berupa lembaga swadaya masyarakat, organisasi lingkungan dan sejenisnya tidak bisa dilepaskan dari keseluruhan sejarah diskursus pembangunan. Di Indonesia kehadiran organisasi kemasyarakatan seperti itu berkonotasi sebagai organisasi pembangunan non pemerintah atau yang lebih pepuler sebagai non government organization ( $N G O)$. Karena sifatnya yang non pemerintah di masa lalu sering dicurigai kehadirannya dan dianggap sebagai kekuatan yang bisa menggagalkan program pembanguan yang dilakukan pemerintah.

Reaksi dalam bentuk advokasi terhadap ketidakadilan masyarakat yang dilakukan lembaga swadaya masyarakat dan organisasi lingkungan dimainkan oleh para legal lingkungan. Kehadiran mereka tidak mempunyai kepentingan yang bersifat material, tetapi semata karena kepentingan masyarakat dan kepentingan lingkungan. Keberadaan mereka berfungsi sebagai agent pendamping, pendorong, memfasilitasi, serta mewakili masyarakat dalam melakukan penuntutan hak-hak masyarakat atas lingkungan hidup yang telah dirusak dan tercemar akibat perilaku perusahaan. Peran yang dimainkan ditandai dengan adanya pelimpahan kewenangan untuk mewakili masyarakat dalam berbagai upaya penyelesaian sengketa, termasuk dalam menterjemahkan keinginan masyarakat dalam memperjuangkan hak-haknya di pengadilan. Hak-hak masyarakat tersebut, berupa keadilan masyarakat (social justice),

72 WARTA, Vol.10, No. 1, Maret 2007: 68 - 75 
yakni ganti rugi yang memadai, dan keadilan lingkungan (environment justice), yakni berkaitan dengan tuntutan untuk melakukan pemulihan lingkungan hidup.

Keberadaan lembaga swadaya masyarakat dan organisasi lingkungan dalam terminologi Durkheim dalam rangka menjalankan misi solidaritas sebagai kewajiban kodrati kehidupan masyarakat manusia sebab kehidupan manusia tidak bersifat individu melainkan bermasyarakat. Hukum yang dipakai oleh masyarakat berpadanan dengan tipe solidaritas masyarakat. Solidaritas ada dua, yakni solidaritas mekanik dan solidaritas organik. Solidaritas mekanik mensyaratkan adanya suatu ikatan yang bersifat mekanis antara para warga masyarakat. Solidaritas organik memberikan kelonggaran kepada masingmasing anggota masyarakat untuk menjalin hubungan satu sama lain, tanpa adanya campur tangan. Kehidupan bersama akan terbina dengan memberi kebebasan kepada para anggota bekerja dan menjalin hubungan dengan orang lain ${ }^{8}$.

Gerakan sosial yang berkembang ke advokasi lingkungan dimainkan oleh para legal lingkungan, yakni aktivis lingkungan yang memiliki keterampilan memadai dan mempunyai kamauan dan kemampuan untuk mendayagunakan pengetahuan dan keterampilannya untuk memfasilitasi ikhtiar perwujudan hakhak lingkungan masyarakat yang menjadi korban (pencemaran) lingkungan. Mereka bekerja untuk melakukan advokasi lingkungan dalam kasus perusakan dan pencemaran lingkungan? .

Dalam menjalankan pekerjaannya mereka bekerja sama dengan masyarakat untuk melakukan advokasi, yang didahului dengan dialog terhadap persoalan yang sedang terjadi. Di samping itu, mereka berusaha memfasilitasi masyarakat memikirkan dan mencari jalan keluar persoalan yang sedang dihadapi masyarakat. Setelah itu, mereka melakukan aksi bersama untuk menyuarakan dan memperjuangkan hak-hak masyarakat, yang didukung dengan adanya lembaga dan jaringan kerja antar lembaga (organisasi) untuk melakukan advokasi lingkungan, baik melalui forum pengadilan maupun non pengadilan ${ }^{10}$.

\section{SIMPULAN DAN SARAN}

\section{a. Simpulan}

1. Dalam pelatihan advokasi lingkungan masyarakat korban pencemaran sekalipun rata-rata sebagai petani dan berpendidikan rendah tetapi tampak semangat untuk mengikuti materi pelatihan. Mereka ingin 
mengetahui banyak bagaimana cara memperjuangkan lingkungannya yang sudah tercemar oleh pihak-pihak (perusahaan) yang dinilai tidak bertanggung jawab.

2. Dalam melakukan upaya advokasi masyarakat dibantu oleh LSM Gita Pertiwi. Cara kerja atau upaya yang dilakukan dengan bekerja sama dengan masyarakat untuk melakukan advokasi, yang didahului dengan dialog terhadap persoalan pencemaran lingkungan yang sedang terjadi. Di samping itu, mereka berusaha memfasilitasi masyarakat memikirkan dan mencari jalan keluar persoalan yang sedang dihadapi masyarakat. Setelah itu, mereka melakukan aksi bersama untuk menyuarakan dan memperjuangkan hak-hak masyarakat. Dengan adanya bantuan LSM Gita Pertiwi pelaksanaan pengabdian masyarakat melalui pelatihan advokasi lingkungan dapat berjalan dengan baik.

\section{b. Saran-saran}

1. Perlu adanya pelatihan lebih lanjut mengenai pendidikan advokasi bagi masyarakat korban pencemaran lingkungan. Hal ini penting supaya mereka mengetahui hak dan kewajibannya terhadap lingkungan, sehingga pada akhirnya masyarakt tanpa digerakan lembaga advokasi mereka akan bergerak sendiri.

2. Di samping itu mereka amat membutuhkan pelatihan advokasi dalam tataran praktis di lapangan ketika melakukan demonstrasi, agar dalam melakukan advokasi tidak anarkhis. Sebab di beberapa tempat demonstrasi masalah lingkungan berakhir dengan kerusuhan.

\section{DAFTAR PUSTAKA}

Absori. 2002. Penegakan Hukum Lingkungan pada Era Perdagangan Bebas. Surakarta: Universitas Muhammadiyah Surakarta Press

Hamzah. 2005. Penegakan Hukum Lingkungan. Jakarta: Arikha Media Cipta.

Harun M. Husein. 1992. Lingkungan Hidup, Masalah Pengelolaan dan Penegakan Hukumnya. Jakarta: Bumi Aksara.

74 WARTA, Vol.10, No. 1, Maret 2007: 68 - 75 
Indro Sugianto. 2003. "Mensinergikan Kekuatan Masyarakat Sipil dalam Penegakan Hukum Lingkungan". Makalah Diskusi Panel. Kerja sama Program Magister Ilmu Lingkungan Undip dengan Kementerian Lingkungan Hidup. Semarang, 11 Nopember 2003.

Kirkpatrick Sale. 1996. Revolusi Hijau, Sebuah Tinjauan Historis-Kritis Gerakan Lingkungan Hidup di Amerika Serikat. Jakarta: Yayasan Obor Indonesia.

Koenadi Hardjasoemantri. 2000. Hukum Tata Lingkungan. Yogyakarta: Gadjahmada University Press.

Rachmadi Usman. 2003. Pembaharuan Hukum Lingkungan Nasional. Bandung: PT Citra Aditya Bakti.

Sudharto P. Hadi. 2002. Dimensi Hukum Pembangunan Berkelanjutan. Semarang: Badan Penerbit Universitas Diponegoro.

Ton Dietz. 1998. Pengakuan Hak atas Sumber Daya Alam. Pengantar Dr. Mansour Faakih, Refleksi Gerakan Lingkungan. Yogyakarta: Remdec, Insist Press dan Pustaka Pelajar. 
76 WARTA, Vol.10, No. 1, Maret 2007: 68 - 75 
78 WARTA, Vol.10, No. 1, Maret 2007: 68 - 75 